\title{
PATHOGENICITY CHARACTERISTICS OF STOCKED AND FRESH YEASTS STRAINS
}

\author{
Guilherme Maranhão Chaves ${ }^{1}$; Maria Auxiliadora de Queiroz Cavalcanti ${ }^{1 *}$; Ana Lúcia Figueiredo Porto² \\ ${ }^{1}$ Departamento de Micologia, Centro de Ciências Biológicas, Universidade Federal de Pernambuco, PE, Brasil. ${ }^{2}$ Setor de \\ Biotecnologia, Laboratório de Imunopatologia Keizo Assami, Centro de Ciências Biológicas, Universidade Federal de \\ Pernambuco, PE, Brasil.
}

Submitted: April 25, 2002; Returned to Authors: January 16, 2003; Approved: September 13, 2003

\begin{abstract}
In order to evaluate the pathogenicity of yeasts of medical importance, 15 strains stocked in mineral oil at the URM Culture Collection of the Department of Mycology, Biological Sciences Centre, Federal University of Pernambuco and 15 fresh strains isolated from AIDS patients interned at the Clinical Hospital, Centre of Health Sciences, Federal University of Pernambuco, were selected. As pathogenicity characteristics, the ability to grow at $37^{\circ} \mathrm{C}$ and production of phospolipase and proteinase were tested. All samples grew at $37^{\circ} \mathrm{C}$ and exhibited proteinase activity. However when tested on solid medium, the proteinase activity was negative. Among 15 stocked samples, 13 (86.66\%) were phospholipase positive and two (13.34\%) were phospholipase negative. From the 15 samples isolated from AIDS patients, four (26.66\%) were phospholipase positive and 11 (73.34\%) were phospholipase negative.
\end{abstract}

Key words: yeasts, pathogenicity, temperature, phospholipase, proteinase.

\section{INTRODUCTION}

Candidosis is an infection caused by Candida species. It can be acute or chronic, superficial or deep and its clinical spectrum can be so variable that a more specific definition can not be given (16).

The principal etiological agent of candidosis is Candida albicans. The majority of the studies show that this specie constitute at least $60 \%$ of Candida species isolated from clinical samples. Since this yeast is a part of the normal human microbiota, candidosis can be considered an opportunistic infection $(16,17,29)$.

However, some considerations have to be taken because another Candida species have been frequently reported in literature as etiological agents of candidosis, like for example: $\mathrm{C}$. tropicalis, C. parapsilosis, C. krusei, C. guilliermondii, C. glabrata. C. kefir, C. lusitaniae, C. viswanathii e C. famata. All these species were already isolated from clinical samples $(7,23)$.

Trichosporon species can cause many human infections similar to candidosis. The disseminated form, denominated thricosporonosis (acute or chronic), can be life-threatening in patient with malign diseases, mainly imunossupressed patients $(11,14)$.

The ability of some fungi to grow up at $37^{\circ} \mathrm{C}$, and also to produce enzymes like phospholipases and proteinases permit the establishment of a relation with pathogenicity $(13,16,20$, 22,25,33).

The purposes of the present study were: a) To confirm the identification of 15 samples of stocked yeasts at the URM Culture Collection, through biochemical and physiological assays; b) To determinate pathogenicity characteristics in vitro, of these stocked samples and also of yeasts isolated from AIDS patients including growth, at $37^{\circ} \mathrm{C}$, and enzymatic (phospholipase and proteinase) activity.

\section{MATHERIALS AND METHODS}

\section{Strains}

Thirty yeasts strains isolated from clinical samples were selected: 15 stocked in mineral oil at the URM Culture Collection of

* Corresponding author. Mailing address. Departamento de Micologia, Centro de Ciências Biológicas, Universidade Federal de Pernambuco. Av. Prof. Nelson Chaves, s/n, Cidade Universitária. 50670-420, Recife, PE, Brasil. Fax: (+5581) 3271-8482. E-mail: xiliamac@terra.com.br 
Department of Mycology, Centre of Biological Sciences, Federal University of Pernambuco and 15 fresh samples isolated from AIDS patients interned at the Clinical Hospital, Centre of Health Sciences, Federal University of Pernambuco (Tables 1 and 2).

\section{Sample Reactivation}

The stocked samples preserved in mineral oil were reactivated by growth in glycoside broth and then transferred to slants containing Sabouraud agar plus yeast extract $(\mathrm{SAB}+\mathrm{YE})$.

\section{Culture Media}

For confirmation of the identification: Bovine bile water medium, $\mathrm{C}$ and $\mathrm{N}$ basic medium and sugar fermentation medium (17). For characterization of enzymatic activity: Semiquantitative phospholipase determination medium (28) modified, substituting $20 \mathrm{~g}$ of sterilized egg yolk (Difco) by two natural egg yolk, and qualitative proteinase determination medium $(17,18)$. For species confirmation, the classical methods of Lodder (19), Kreger van Rij (15) and Barnett et al. (1) were utilized.

\section{Pathogenicity characteristics detection Growth at $37^{\circ} \mathrm{C}$}

The yeasts samples were smeared in duplicate into $\mathrm{SAB}+\mathrm{YE}$ slants, the first slant kept at room temperature $\left(28^{\circ} \mathrm{C} \pm 1^{\circ} \mathrm{C}\right)$ and

$\begin{array}{lccl}\text { Species } & \begin{array}{c}\text { Registration } \\ \text { number } \\ \text { (URM) }\end{array} & \begin{array}{c}\text { Storage } \\ \text { period } \\ \text { (years) }\end{array} & \text { Origin } \\ \begin{array}{l}\text { Candida } \\ \text { albicans }\end{array} & 720 & 44 & \begin{array}{l}\text { Bronchoalveolar } \\ \text { secretion }\end{array}\end{array}$

the other one incubated at $37^{\circ} \mathrm{C}$. They were monitored for $72 \mathrm{~h}$, with the purpose of comparing the cultures growth.

\section{Enzymatic Activity}

Semi-quantitative phospholipase detection (28): yeasts, grown for $72 \mathrm{~h}$ were inoculated on the referred culture medium and incubated at room temperature. Cultures were observed for 10 to 15 days for formation of an opaque zone of precipitation, measured in centimeters. Phospholipase Zone (PZ) was calculated as the ratio between the diameter of the colony and the diameter of colony plus the diameter of zone of precipitation. When PZ was $=1.0$, the samples tested were considered phospholipase negative and when $\mathrm{PZ}$ was $<1.0$, they were considered phospholipase positive.

\section{Qualitative proteinase detection (17)}

The strains were inoculated at the same conditions of phospholipase detection assay. When a transparent zone of precipitation occurred, the result was considered positive, regardless the diameter.

\section{Quantitative proteinase detection (18)}

The strains were inoculated into $250 \mathrm{~mL}$ flasks containing $50 \mathrm{~mL}$ of Sabouraud broth. The flasks were incubated at room temperature, 120 r.p.m., for $24 \mathrm{~h}$ and the number of cells were adjusted to $10^{6} / \mathrm{mL}$ using a Neubauer chamber. The strains were inoculated into $250 \mathrm{~mL}$ flasks containing $50 \mathrm{~mL}$ of casein enzymatic broth. The flasks were incubated at room temperature, 120 r.p.m., for $48 \mathrm{~h}$, and $5 \mathrm{~mL}$ of each sample were frozen at $0^{\circ} \mathrm{C}$ until enzymatic dosage was done. The frozen samples were thawn 
at room temperature for $1 \mathrm{~h}$, centrifuged for $15 \mathrm{~min}$. at 2,000 $\mathrm{xg}$ and the supernatants submitted to proteinase activity determination. The assay mixture $(0.25 \mathrm{~mL}$ of azocasein $1 \% \mathrm{w} / \mathrm{v}$ on Tris- $\mathrm{HCl}$ buffer, $\mathrm{pH}=7.6$, and $0.15 \mathrm{~mL}$ of the medium containing proteinase) was incubated for one hour at room temperature, and then $1.2 \mathrm{~mL}$ of trichloroacetic acid (TCA) $10 \% \mathrm{w} / \mathrm{v}$ was added. The samples were centrifuged for $10 \mathrm{~min}$. at $8,000 \mathrm{xg}$, at $4^{\circ} \mathrm{C}$. Then $0.8 \mathrm{~mL}$ of the supernatants were transferred to test tubes containing $1.4 \mathrm{~mL}$ of sodium hydroxide $1 \mathrm{M}$. Each assay was performed twice. Negative controls comprised by solutions without the enzyme were included in the tests. The absorbancy was read at $440 \mathrm{~nm}$ (Shimatzu UV-visible spectophotometer). The proteinase unit, expressed as U.mL ${ }^{-1}$, was defined as the amount of enzyme required to produce a variation of absorbancy equal to 1 .

\section{RESULTS AND DISCUSSION}

\section{Strains Viability}

The stocked yeasts strains at the URM Culture Collection (15) were viable regardless the time of preservation, presenting growth when transferred from glycoside broth to $\mathrm{SAB}+\mathrm{YE}$. Confirmation of the identification: All stocked yeasts strains (15) showed patterns of sugar assimilation and fermentation that corresponded to the specie previously identified. However, the $C$. albicans samples lost their ability to produce clamidospore on bovine bile water, suggesting physiological modifications caused by genetic instability due to the storage for long periods on mineral oil (36).

\section{Pathogenicity Characteristics Growth at $37^{\circ} \mathrm{C}$}

All strains were able to grow at $37^{\circ} \mathrm{C}$. Twenty-eight Candida and two Trichosporon pullulans strains grew similarly at room temperature and $37^{\circ} \mathrm{C}$.

The ability of some fungi to grow at $37^{\circ} \mathrm{C}$ is cited in the literature as a pathogenicity factor $(16,17,22,29,35)$. Histoplasma capsulatum and Criptococcus neoformans, frequently isolated from animals without causing disease, are human pathogens, probably because this animals higher body temperature in than humans (35).

\section{Phospholipase Activity}

From the 15 strains stocked at the URM Culture Collection, $13(86.66 \%)$ were phospholipase positive and two (13.34\%) were phospholipase negative. From the 13 phospholipase positive strains, six (46.15\%) were C. albicans, three (23.08\%) C. parapsilosis, two (15.39\%) C. tropicalis, one (7.69\%) C. glabrata and one (7.69\%) C. krusei (Fig. 1).

The Phospholipase Zone (PZ) for the 15 stocked strains ranged from 0.179 to 0.310 . One strain presented a PZ band $0.179,11$ strains bands between 0.204 and 0.270 and one strain presented a PZ band 0.310 (Table 3 ).
From the 15 fresh strains isolated from AIDS patients, four (26.66\%) were phospholipase positive and 11 (73.34\%) were negative. From the four positive strains, three (75\%) were $C$. albicans and one (25\%) C. parapsilosis (Fig. 1).

The Phospholipase Zone (PZ) for the 15 fresh samples ranged from 0.276 to 0.482 , with one sample presenting PZ band 0.276 , one 0.319 , one 0.459 and one 0.482 (Table 4 ).

Among the stocked strains, a higher percentage for phospholipase activity was observed. In addition to $C$. albicans, other Candida species were also able to produce phospholipase. Only two strains did not produce phospholipase: one $C$. parapsilosis and one Trichosporon pullulans. In general, the strains presented low PZ values, indicating high phospholipase activity.

Table 3. Phospholipase and proteinase activity of the yeasts strains stocked in The URM Cultures Collection.

\begin{tabular}{lccc}
\hline \multicolumn{1}{c}{ Species } & $\begin{array}{c}\text { URM } \\
\text { Registration } \\
\text { number }\end{array}$ & $\begin{array}{c}\text { Phospholipase } \\
\text { activity (PZ) }\end{array}$ & $\begin{array}{c}\text { Proteinase } \\
\text { activity }\end{array}$ \\
\hline Candida albicans & 720 & 0.310 & $1.066 \mathrm{U} / \mathrm{mL}$ \\
C. albicans & 743 & 0.217 & $1.386 \mathrm{U} / \mathrm{mL}$ \\
C. albicans & 2224 & 0.270 & $0.673 \mathrm{U} / \mathrm{mL}$ \\
C. albicans & 2252 & 0.259 & $1.053 \mathrm{U} / \mathrm{mL}$ \\
C. albicans & 2253 & 0.260 & $0.733 \mathrm{U} / \mathrm{mL}$ \\
C. albicans & 3622 & 0.223 & $0.726 \mathrm{U} / \mathrm{mL}$ \\
C. glabrata & 943 & 0.204 & $1.353 \mathrm{U} / \mathrm{mL}$ \\
C. krusei & 934 & 0.261 & $0.803 \mathrm{U} / \mathrm{mL}$ \\
C. parapsilosis & 729 & - & $0.973 \mathrm{U} / \mathrm{mL}$ \\
C. parapsilosis & 3621 & 0.179 & $0.686 \mathrm{U} / \mathrm{mL}$ \\
C. parapsilosis & 3624 & 0.240 & $0.700 \mathrm{U} / \mathrm{mL}$ \\
C. parapsilosis & 3627 & 0.254 & $0.686 \mathrm{U} / \mathrm{mL}$ \\
C. tropicalis & 1150 & 0.269 & $0.673 \mathrm{U} / \mathrm{mL}$ \\
C. tropicalis & 916 & 0.267 & $0.860 \mathrm{U} / \mathrm{mL}$ \\
T. pullulans & 1323 & - & $0.830 \mathrm{U} / \mathrm{mL}$ \\
\hline
\end{tabular}

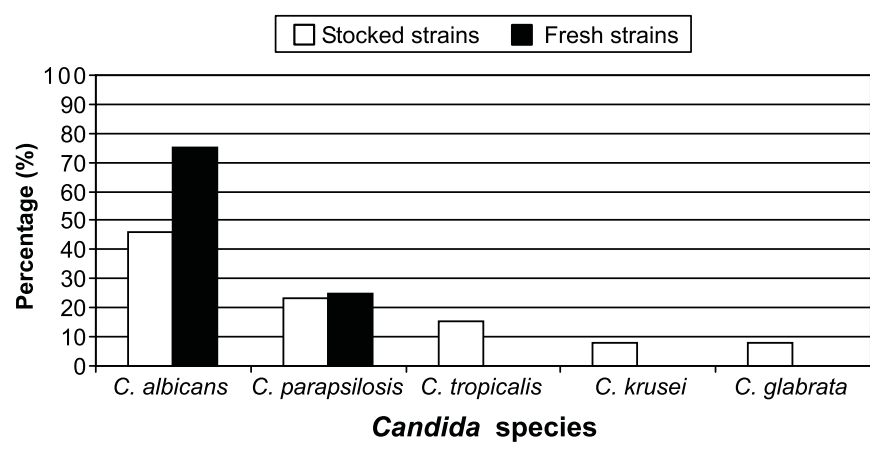

Figure 1. Phospholipase activity percentage in Candida strains. 
Table 4. Phospholipase and proteinase activity of the yeasts isolated from AIDS patients interned at The Clinical Hospital, Federal University of Pernambuco.

\begin{tabular}{lccc}
\hline \multicolumn{1}{c}{ Species } & $\begin{array}{c}\text { Registration } \\
\text { number }\end{array}$ & $\begin{array}{c}\text { Phospholipase } \\
\text { activity (PZ) }\end{array}$ & $\begin{array}{c}\text { Proteinase } \\
\text { activity }\end{array}$ \\
\hline Candida albicans & 16 & - & $0.993 \mathrm{U} / \mathrm{mL}$ \\
C. albicans & 84 & 0.319 & $0.993 \mathrm{U} / \mathrm{mL}$ \\
C. albicans & 14 & - & $0.946 \mathrm{U} / \mathrm{mL}$ \\
C. albicans & 18 & 0.482 & $0.780 \mathrm{U} / \mathrm{mL}$ \\
C. albicans & 23 & 0.276 & $0.706 \mathrm{U} / \mathrm{mL}$ \\
C. albicans & 97 & - & $0.706 \mathrm{U} / \mathrm{mL}$ \\
C. glabrata & 64 & - & $0.714 \mathrm{U} / \mathrm{mL}$ \\
C. krusei & 58 & - & $0.993 \mathrm{U} / \mathrm{mL}$ \\
C. parapsilosis & 33 & 0.459 & $0.933 \mathrm{U} / \mathrm{mL}$ \\
C. parapsilosis & 35 & - & $0.840 \mathrm{U} / \mathrm{mL}$ \\
C. parapsilosis & 69 & - & $0.860 \mathrm{U} / \mathrm{mL}$ \\
C. parapsilosis & 44 & - & $0.886 \mathrm{U} / \mathrm{mL}$ \\
C. tropi & 08 & - & $0.726 \mathrm{U} / \mathrm{mL}$ \\
C. tropicalis & 34 & - & $0.710 \mathrm{U} / \mathrm{mL}$ \\
T. pullulans & 86 & - & $0.726 \mathrm{U} / \mathrm{mL}$ \\
\hline
\end{tabular}

Among the fresh strains, there was a lower number of phospholipase positive samples. In addition, only one strain of C. parapsilosis was able to present phospholipase activity. It was also observed that one C. albicans and one of T. pulullans strain were phospholipase negative.

Saramanayake et al. (32), Mayser et al. (21) and Candido et $a l$. (5), studying Candida strains isolated from oral cavity of patients presenting or not lesions, only detected phospholipase activity only in C. albicans, and observed that $C$. glabrata, $C$. parapsilosis and $C$. tropicalis did not produce phospholipase. However, Shimizu et al. (34), testing yeasts strains isolated from clinical samples, detected phospholipase activity in other species of Candida, such C. parapsilosis, C. tropicalis, $C$. guilliermondii and $C$. krusei. However these strains produced lower quantity of enzyme than $C$. albicans.

Oliveira et al. (26), investigating yeasts samples isolated from oral cavity from cancer patients, observed that all isolates (24 C. albicans and one C. krusei) were able to produce phospholipases, but showed a large PZ variation (0.12 to 0.61 ). In our study, phosplipase activity was detected in all Candida species tested, contributing with the authors which have found the same results.

Although some authors such as Vidotto et al. (37) and Ghannoum (9) have indicated that Trichosporon is able to produce phospholipase, Mayser et al. (21) did not observe phospholipase activity in T. cutaneum, T. capitatum and T. inkin. The literature does not refer T. pullulans showing positive phospholipase activity.

Price et al (28), comparing the plate method and biochemical assays, verified that the easy method using a solid medium is very useful to investigate the variability of phospholipase activity of different clinical samples. In addition, these authors also verified that some isolates frozen for long periods at $-20^{\circ} \mathrm{C}$ and $-80^{\circ} \mathrm{C}$ presented a decrease in phospholipase activity. These data do not agree with the results obtained in the present study, since strains preserved in mineral oil maintained the enzymatic activity. The high phospholipase activity was already expected, because all samples in the present study were isolated from patients. However, a lower phospholipase activity was observed among the fresh strains isolated from AIDS patients.

Willis et al. (38) analyzed the effect of fluconazole and nystatin on phospholipase production and observed that fluconazole decreased phospholipase activity in clinical samples isolated from oral cavity of diabetes melittus patients. It is likely that the samples of our study have decreased their ability to produce phospholipase as consequence of antifungal tratment to which the patients interned at The Clinical Hospital have been submitted (azoles and nystatin).

\section{Proteinase Activity}

Qualitative proteinase determination: None of the strains, including the stocked and the fresh strains produced proteinase in the casein medium, suggesting that this solid medium is not an suitable alternative for yeasts proteinase activity detection. Quantitative proteinase determination: This test indicated that all stocked strains (15) were able to produce detectable levels of proteinase: three strains produced from 0.673 to $0.686 \mathrm{U} \cdot \mathrm{mL}^{-1}$;

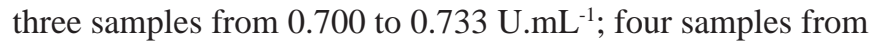
0.803 to $0.860 \mathrm{U} \cdot \mathrm{mL}^{-1}$; one sample produced $0.973 \mathrm{U} \cdot \mathrm{mL}^{-1}$ and four samples from 1.053 to $1.386 \mathrm{U} \cdot \mathrm{mL}^{-1}$. The samples $1150(C$. parapsilosis) and 2224 (C. albicans) was the best proteinase producer $\left(0.673 \mathrm{U} \cdot \mathrm{mL}^{-1}\right)$. The strain 743 (C.albicans) produced more proteinase (1.386 U.mL $\mathrm{mL}^{-1}$ ) (Table 3 ).

All the fresh samples isolated from AIDS patients (15) also produced detectable levels of proteinase. It was observed that seven samples produced from 0.706 to $0.780 \mathrm{U} \cdot \mathrm{mL}^{-1}$; three samples from 0.840 to $0.886 \mathrm{U} \cdot \mathrm{mL}^{-1}$ and five samples from 0.933 to 0.993 U.mL $\mathrm{mL}^{-1}$. The samples 23 (C. albicans) and 97 (C. parapsilosis) produced less proteinase $\left(0.706 \mathrm{U}^{\mathrm{mL}} \mathrm{m}^{-1}\right)$. The samples 16 (C. albicans) 84 (C. albicans) and 58 (C. krusei) were the best proteinase producers $\left(0.993 \mathrm{U} \cdot \mathrm{mL}^{-1}\right)$ (Table 4).

Wu et al. (39), analyzing clinical samples of $C$. albicans, $C$. tropicalis and $C$. parapsilosis from oropharyngeal secretion, investigated SAPs genes expression on a proteinase inductor medium (YCB-BSA) and observed that $C$. albicans samples were more proteolytic than other species of the same genus.

Bistoni et al. (2) and Rüchel et al. (31) demonstrated that Candida parapsilosis samples virulence was low or absent even in immunossupressed animals. De Bernardis et al. (8) however, observed elevated in vitro production of proteinase but one of the yeasts samples did not produce acid proteinase in vivo. This same authors, comparing the acid proteinase 
production by $C$. albicans and $C$. parapsilosis isolated from vaginal secretion, observed a very similar enzyme production kinetics. Nevertheless, Rüchel et al., (30), developing an infection model with phagocitic cells, showed that $C$. parapsilosis did not produced acid proteinase in vivo.

C. albicans is able to produce proteinases in vitro in high quantities $(3,6,8,12,24,30)$. Chakabrati et al. (6) call the attention for the proteinase activity detection by $C$. tropicalis, $C$. parapsilosis and $C$. glabrata isolated from clinical samples like anal mucous secretion, sputum, oropharyngeal secretion and urine, where the proteinase production was never investigated. According to those authors, this test is important for the definition of the microorganism as etiological agent or colonizer, in sites where they are part of the normal microbiota.

In the present study, it was observed that stocked strains presented a higher proteinase activity than the fresh samples recovered from AIDS patients.

The literature have recently pointed out that anti-retroviral agents utilized in AIDS patients may cause proteinase inhibition in Candida species, like C. albicans, C. parapsilosis, $C$. tropicalis and $C$. lusitaniae $(10,27)$. The aspartic proteinase secreted by Candida have similarities to the HIV aspartic proteinases (9). It is likely that in the present study proteinase activity of the fresh strains have been inhibited, once the patients were submitted to anti-retroviral therapy.

\section{RESUMO}

\section{Características de patogenicidade de amostras de leveduras preservadas e recém-isoladas}

Com o objetivo de avaliar a patogenicidade de leveduras de interesse médico, foram selecionadas 15 amostras preservadas em óleo mineral na Micoteca URM, Centro de Ciências Biiológicas, Universidade Federal de Pernambuco e 15 isolados recentes, provenientes de amostras clínicas de pacientes com AIDS, internados no Hospital das Clínicas, Centro de Ciências da Saúde, Universidade Federal de Pernambuco. Com relação as características de patogenicidade, foram avaliados a capacidade desses microorganismos crescerem a $37^{\circ} \mathrm{C}$, bem como apresentarem atividade de fosfolipase e protease. As 30 amostras cresceram a $37^{\circ} \mathrm{C}$ e apresentaram atividade quantitativa de protease, entretanto não apresentaram essa atividade quando testadas em meio sólido. Das 15 amostras preservadas, 13 $(86,66 \%)$ apresentaram atividade fosfolipase positiva e duas $(13,34 \%)$ atividade fosfolipásica negativa e das 15 amostras isoladas de pacientes com AIDS, quatro $(26,66 \%)$ apresentaram atividade de fosfolipase positiva e $11(73,34 \%)$ apresentaram atividade fosfolipásica negativa.

Palavras-chave: leveduras, patogenicidade, temperatura, fosfolipase, protease.

\section{REFERENCES}

1. Barnett, J.A.; Payne R.W.; Yarrow D. Yeasts: characteristics and identification. 4 ed. Cambridge, Cambridge: University Press, 1990, $1002 \mathrm{p}$

2. Bistoni, F.; Vecchiiarelli, A.; Cenci, A.; Sbaraglia, G.; Perito, S.; Cassone, A. A comparision of experimental pathogenicity of Candida species in cyclophophamide-immunodepressed mice. Sabouraudia, 22:409-418, 1984.

3. Borg-von, M.; Grünes, V. Characterization of two monoclonal antibodies against secretory proteinase of Candida tropicalis DSM 4238. J. Med. Vet. Mycol., 21:1-15, 1993.

4. Borg-von, M.; Meyer, I.; Thomssen, R.; Wurzner R.; Sanglard D.; Monod HIV-Protease inhibitors reduce cell adherence of Candida albicans by inhibition of yeast secreted aspartic proteases. J. Invest. Dermat., 113(5):747-751, 1999.

5. Candido, C.C.; Azevedo, R.V.P.; Komesu, M.C. Enzimotipagem de espécies do gênero Candida isoladas da cavidade bucal. Rev. Soc Bras. Med. Trop., 33(5):437-442, 2000.

6. Chakrabarti, A.; Nayak, N.; Talwar, P. In vitro proteinase production by Candida species. Mycopathologia, 141:163-168, 1991.

7. Coleman, D.C.; Rinaldi, M.G.; Haynes, K.A; Rex, J.H.; Summerbell, R.C.; Anaisse, E.J.; Li, A.; Sullivan, D.J. Importance of Candida species other than Candida albicans as opportunistic pathogens. Med Mycol, 36:156-165, 1998.

8. De Bernardis, F.; Morelli, L.; Ceddia, T.; LorenzenI, R.; Cassone, A Experimental pathogenicity and acid proteinase secretion of vaginal isolates of Candida parapsilosis. J. Med. Vet. Mycol., 28:125-137, 1990.

9. Ghannoum, M.A. Potential role of phospholipases in virulence and fungal pathogenicity. Clin. Microb. Ver., 13(1):122-143, 2000.

10. Gruber, A.; Berlit, J.; Speth, C.; Lass-Florl; Kofler, G.; Nagl, M.; Borg Von Zepelin, M.; Dierich, M.P.; Wurzner R. Dissimilar attenuation of Candida albicans virulence properties by human immunodeficiency virus type 1 protease inhibitors. Immunobiology, 201(1):133-144, 1999

11. Hsu, C.F.; Wang, C.G.; Hung, C.S.; Cheng, S.N., Chen, Y.H.; Chu, M.L. Trichosporon beigelli causing oral mucosit and fungaemia: report of one case. Chung Hua Min Kuo Hsiao Erh Ko I Hsueh Hui Tsa Chih, 39(3):191-194, 1998.

12. Hube, B.; Turver, C.J.; Odds, F.C.; Eiffert, H.; Boulnois, G.J.; Köchel $\mathrm{H}$.; RücheL, R. Sequence of the Candida albicans gene enconding the secretory aspartate proteinase. J. Med. Vet. Mycol., 29:129-132, 1991.

13. Khozel, T.R. Virulence factors of Cyptococcus neoformans. Trends Microbiol., 3:295-299, 1995.

14. Krcmery, V.Jr.; Mateicka, F.; Kunova, A. Spanik, S.; Giarfas, J.; Sycova, Z.; Trupl, J. Hematogenous trichosporonosis in cancer patients: report of 12 cases including 5 during prophylaxis with itraconazol. Support Care Cancer, 7(1):39-43, 1999.

15. Kreger-Van RIJ, N.J.W. The yeast: a taxonomic study. 3.ed. Elsevier Sci. Publication: Amsterdan, 1984.

16. Kwon Chung; Bennet. Med. Mycol., 615. 1992.

17. Lacaz, C.S.; Porto, C.; Martins, J.E.C. Micologia Médica: fungos, actinomycetes e algas de interesse médico. $8^{\mathrm{a}}$ ed., São Paulo: SarverEDUSP, 1991. 695p.

18. Leighton, T.J.; Doi, R.H. The relationship of serine proetease activity to RNA polymerase modification and sporulation in Bacillus subtillis. J. Molec. Biol., 76:103-122, 1973.

19. Lodder, J. The Yeast: a taxonomic study. Oxford: North Holland Publishing Company, 1970. 1385p.

20. Mago, K. Subcellular localisation of enzymes of phospholipase metabolism in Candida albicans. J. Med. Vet. Mycol., 28:355-362, 1990. 
21. Mayser, P.; Laabs, S.; Heuer, K.; Gründer, K. Detection of extracellular phospholipase activity in Candida albicans and Rhodotorula rubra. Mycopathologia, 135:149-155, 1996.

22. Mcdonald, F.; Odds, F.C. Virulence for mice of a proteinase secreting strain of Candida albicans and proteinase deficient mutant. J. Gen. Microbiol., 129:431-438, 1983.

23. Milan, E.P.; Malheiros, E.S.; Fischman, O.; Colombo, A.L. Evaluation of the auxacolor system for the identification of clinical yeasts isolates. Mycopathologia, 137:153-157, 1997.

24. MilenwskI, S.; MigninI, F.; CovellI, I.; Borowsky, E. Specific inhibition of acid proteinase secretion in Candida albicans by LYS-NVA-FMDP. J. Med. Vet. Mycol., 32:1-11, 1994.

25. Neder, R.N. Microbiologia: Manual de Laboratório. São Paulo, ed. Nobel, 98p, 1992.

26. Oliveira, E.E.; Silva, S.C.; Soares, A.J.; Attux, C.; Cruvinel, B.; Silva, M.R.R. Toxinas killer e produção de enzimas por Candida albicans isoladas da mucosa bucal de pacientes com câncer. Rev. Bras. Med. Trop., 31:523-527, 1998.

27. Pichova, I; Pavlickova, L; Dostal, J; Dolejsi, E; HruskovaHeidingsfeldova, O; Weber, J; Ruml, T.; Soucek, M. Secreted aspartic proteases of Candida albicans, Candida tropicalis, Candida parapsilosis and Candida lusitaniae. Inhibition with peptidomimetic inhibitors. Eur. J. Biochem., 268(9):2669-2677, 2001.

28. Price, M.F.; Wilkinson, I.D.; Gentry, L.O. Plate Method for detection of phospholipase activity in Candida albicans. Saboraudia, 20:714, 1982 .

29. Rippon, J.W. Medical Mycology: Hongos y Actinomicetos Patógenos. $3^{a}$ ed., México: Copyright, 1990, 855p.
30. RücheL, R. A variety of Candida proteinases and their possible targets of proteolytic attack in the host. Zbl. Bakt. Mikrob. Hyg., 257(2):266-274, 1984.

31. RucheL, R.; Boning, B.; Borg, M. Characterisation of a secretory proteinase of Candida parapsilosis and evidence for the absence of enzyme during infection in vitro. Infect. Immun., 56:411-419, 1986.

32. Samaranayake, L.P.; Raeside, J.M.; Macfarlane, T.W. Factors affecting the phospholipase activity of Candida species in vitro. $J$. Med. Vet. Mycol., 22:201-207, 1984.

33. Samuels, K.D.Z.; Heale, J.B.; Lewellyn, M. Characteristics relating to the patogenicity of Metarhizium anisopliae, toward Nilaparvata lugens. J. Invertebr. Pathol., 53:25-31, 1989.

34. Shimizu, M.T. Fosfolipase em espécies de Candida. Rev. Microbiol., 20:338-341, 1989 .

35. Sidrim, J.J.C; Moreira, J.L.B. Fundamentos Clínicos e Laboratoriais da Micologia Médica. 1 ${ }^{\mathrm{a}}$ ed., Rio de Janeiro: Guanabara Koogan, $1999,287 \mathrm{p}$.

36. Smith; Onions The preservation and maintenance of living fungi. $1^{\text {a }}$ ed., USA, Commonwealth Mycological Institute, 1983, 51p.

37. Vidotto, V.; Sinnico, A; Di Fraia, D.; Cardaropoli, S.; Aoki, S.; ItoKuwa, S. Phospholipase activity in Criptococcus neoformans. Mycopathologia, 126:119-123, 1996.

38. Willis, A.M.; Coulter, W.A.; Fulton, C.R.; Hayes, J.R.; Bell, P.M.; Lamey, P.J. The influence of antifungal drugs on virulence properties of Candida albicans in patients with diabete mellitus. Oral Surg., 91(3):317-321, 2001.

39. Wu, T; Saramanayake, L.P. The expression of secreted aspartyl proteinases of Candida species in human whole saliva. J. Med. Microbiol., (8):711-720, 1999. 